Synt hesi s and El ect rochem cal Properties of Al doped Li thi um Nanganate Powder s by Spr ay Pyrol ysi s Using Carbonate Aqueous Sol ut i on

\begin{tabular}{|l|l|}
\hline 著者 & H ROSE Shoj i , KODERA Takayuki, OG HARA Takashi \\
\hline $\begin{array}{l}\text { j our nal or } \\
\text { publ i cat i on t i t l e }\end{array}$ & Key Engi neer i ng Nat er i al s \\
\hline vol une & 485 \\
\hline page $r$ ange & $111-114$ \\
\hline year & $2011-07$ \\
\hline URL & ht t p: //hdl . handl e. net /10098/6823 \\
\hline
\end{tabular}




\title{
Synthesis and Electrochemical Properties of Al doped Lithium Manganate Powders by Spray Pyrolysis Using Carbonate Aqueous Solution
}

\author{
Shoji Hirose, Takayuki Kodera, Takashi Ogihara \\ Graduate School of Material Science and Engineering, University of Fukui \\ 3-9-1 Bunkyo, Fukui-shi, Fukui 910-8507 Japan \\ ogihara@matse.u-fukui.ac.jp
}

Keywords: Lithium ion battery, Spray Pyrolysis, Lithium Manganate, Spinel, Aerosol

\begin{abstract}
Al}$ doped $\mathrm{LiMn}_{2} \mathrm{O}_{4}$ powders were prepared by spray pyrolysis using the aqueous solution of manganese carbonate. The aqueous solution, in which manganese carbonate was uniformly dispersed by a surfactant, was used as the starting solution. $\mathrm{Al}_{2} \mathrm{O}_{3}$ nanopowders, $\mathrm{Al}(\mathrm{OH})_{3}$ and $\mathrm{Al}\left(\mathrm{NO}_{3}\right)_{3} \cdot 9 \mathrm{H}_{2} \mathrm{O}$ were used as the doping agent of Al. A scanning electron microscope photograph showed that $\mathrm{Al}$ doped $\mathrm{LiMn}_{2} \mathrm{O}_{4}$ powders had spherical morphology with broad particle size distribution. X-ray diffraction revealed that crystal phase of all samples were good agreement with spinel phase. The rechargeable capacity of $\mathrm{Al}$ doped $\mathrm{LiMn}_{2} \mathrm{O}_{4}$ cathode was about $110 \mathrm{mAh} / \mathrm{g}$ at $1 \mathrm{C}$ regardless of doping agent. $75 \%$ of initial discharge capacity was maintained after 100 cycles.
\end{abstract}

\section{Introduction}

Lithium ion batteries are expected as the energy storage [1] for electric vehicles and hybrid electric vehicles, the load leveling of photovoltaic power generation or the wind power generation. Lithium ion batteries for these applications require cathode materials that combine low cost, high safety and cycle stability at the high rate rechargeable performance. Spinel type $\mathrm{LiMn}_{2} \mathrm{O}_{4}$ [2] is regarded as a promising cathode material for lithium ion batteries due to their advantages such as low cost, abundance resources, non-toxicity and thermally stable. It has been reported that spray pyrolysis is a versatile process that is used to synthesize homogeneous $\mathrm{LiMn}_{2} \mathrm{O}_{4}$ powders [3-5]. However, the toxic and corrosive gases such as $\mathrm{NO}_{\mathrm{X}}, \mathrm{Cl}_{\mathrm{X}}$ and $\mathrm{SO}_{\mathrm{X}}$ are often discharged during the particle formation because the reagent material such as metal nitrate, chloride and sulfide are used as starting solution. It was known [6-8] that the cycle stability $\mathrm{LiMn}_{2} \mathrm{O}_{4}$ was faded due to Jahn-Teller effect in the rechargeable process and the dissolution of $\mathrm{Mn}$ ion at the elevated temperature. These problems have been solved by substituting the foreign metal ion [9] to $16 \mathrm{~d}$ site of the octahedron in the cubic spinel. In this paper, we report the production technique of the $\mathrm{Al}$ doped $\mathrm{LiMn}_{2} \mathrm{O}_{4}$ powders without using the toxic starting material in order to solve this problem.

In this work, the starting solution in which manganese carbonate was uniformly dispersed in aqueous solution by using surfactants was prepared. We tried to prepare $\mathrm{Al}$ doped $\mathrm{LiMn}_{2} \mathrm{O}_{4}$ powders from aqueous solution of manganese carbonate by spray pyrolysis. The powder characteristics of them were investigated in detail. Furthermore, the electrochemical properties of $\mathrm{Al}$ doped $\mathrm{LiMn}_{2} \mathrm{O}_{4}$ cathodes were also estimated by rechargeable capacity and cycle performance.

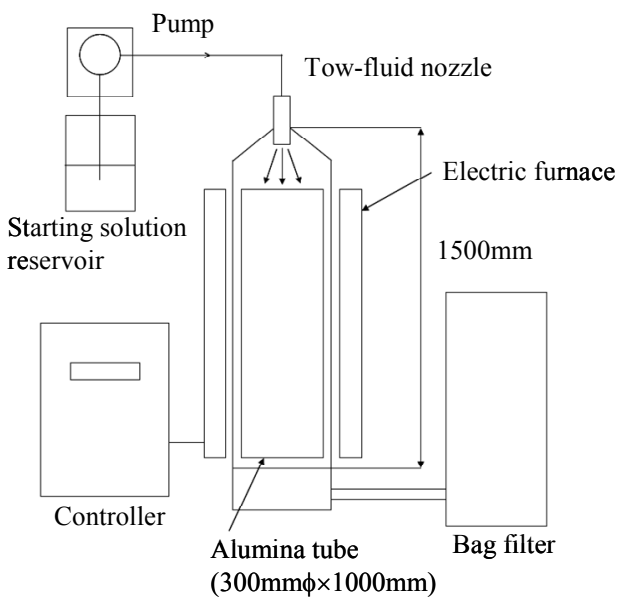

Fig.1 Schematic diagram of spray pyrolysis apparatus. 


\section{Experimental procedure}

$\mathrm{Li}(\mathrm{OH}) \cdot \mathrm{H}_{2} \mathrm{O}$ and $\mathrm{MnCO}_{3}$ were used as starting materials. $\mathrm{Al}_{2} \mathrm{O}_{3}$ nanopowders $(20 \mathrm{~nm})$, $\mathrm{Al}\left(\mathrm{NO}_{3}\right)_{3} \cdot 9 \mathrm{H}_{2} \mathrm{O}$ and $\mathrm{Al}(\mathrm{OH})_{3}$ were used as the doping agent of $\mathrm{Al}$. These were successfully dispersed in aqueous solution by using surfactant at room temperature. The molar ratio of $\mathrm{Li}, \mathrm{Al}$ and $\mathrm{Mn}$ was set to $1.05: 0.05: 1.95$ in the starting solution. The concentration of the solution was $0.25 \mathrm{~mol} / \mathrm{dm}^{3} .0 .25$ $\mathrm{wt} \%$ of surfactant was added to the starting solution. Xanthan gum type surfactant (Roadpole, Rhodia Nicca) was used as surfactant. The $\mathrm{pH}$ of starting solution ranged from 7 to 9 using the $\mathrm{pH}$ adjustment agents such as $\mathrm{CH}_{3} \mathrm{COOH}$. Large spray pyrolysis apparatus (RH-2, Ohkawara Kakohki) was used in this work. Figure 1 shows the schematic diagram of it. This apparatus consisted of two-fluid nozzle, cylindrical type electric furnace with alumina tube $(300 \mathrm{~mm} \phi \times 1000 \mathrm{~mm})$ and bag filter. The mist of starting solution was atomized with a two-fluid nozzle (nozzle diameter: $10 \mu \mathrm{m}$ ). The mists were introduced to an electric furnace by air carrier gas and then pyrolyzed at $800{ }^{\circ} \mathrm{C}$. The flow rate of the carrier gas was $20 \mathrm{dm}^{3} / \mathrm{min}$, and thus the residence time was about $60 \mathrm{~s}$. As-prepared powders were continuously collected using the bag filters. Furthermore, they were calcined at $800{ }^{\circ} \mathrm{C}$ for $4 \mathrm{hr}$ in the electric furnace under an air atmosphere. The particle size, morphology and microstructure of Al doped $\mathrm{LiMn}_{2} \mathrm{O}_{4}$ powders were determined by using scanning electron microscope (SEM, JSM-6390, JEOL). The average particle size of them was determined by randomly sampling 200 particles from SEM photographs. The crystal phase of $\mathrm{Al}$ doped $\mathrm{LiMn}_{2} \mathrm{O}_{4}$ powders were identified by powder X-ray diffraction using $\mathrm{CuK} \alpha$ radiation (XRD, XRD-6100, Shimadzu). The specific surface area of Al doped $\mathrm{LiMn}_{2} \mathrm{O}_{4}$ powders were determined by BET method (BELSORP-mini, Bel Japan). Al doped $\mathrm{LiMn}_{2} \mathrm{O}_{4}$ cathode was prepared using $80 \mathrm{wt} \%$ of $\mathrm{Al}$ doped $\mathrm{LiMn}_{2} \mathrm{O}_{4}$ powders, $10 \mathrm{wt} \%$ of acetylene black and $10 \mathrm{wt} \%$ of fluorine resin. Metal lithium was used as an anode. The polypropylene sheet was used as a separator. $1 \mathrm{~mol} / \mathrm{dm}^{3} \mathrm{LiPF}_{6}$ in ethylene carbonate / 1,2-dimethoxyethane (EC : DEC = 1:1) was used as the electrolyte. 2032 type coin cell was built up in globe box under an argon atmosphere. The rechargeable capacity and cycle life of $\mathrm{Al}$ doped $\mathrm{LiMn}_{2} \mathrm{O}_{4}$ cathode were measured with a battery tester (Hosen, BTS2004) at between 3.5V and 4.3V at $1 \mathrm{C}$.

\section{Results and Discussion}

Figure 2 shows XRD patterns of as-prepared and calcined $\mathrm{Al}$ doped $\mathrm{LiMn}_{2} \mathrm{O}_{4}$ powders. The crystal phase of as-prepared $\mathrm{Al}$ doped $\mathrm{LiMn}_{2} \mathrm{O}_{4}$ powders were agreement with spinel structure $(\mathrm{Fd} 3 \mathrm{~m})$ regardless of doping agent. However, $\mathrm{Mn}_{2} \mathrm{O}_{3}$ phase was also observed in as-prepared powders. It was considered that $\mathrm{MnCO}_{3}$ could not uniformly react with $\mathrm{LiOH} \cdot \mathrm{H}_{2} \mathrm{O}$ in the mist during the pyrolysis. After the calcination, the peaks of $\mathrm{Mn}_{2} \mathrm{O}_{3}$ disappeared and the crystal phase of $\mathrm{Al}$ doped $\mathrm{LiMn}_{2} \mathrm{O}_{4}$ powders converted to the spinel structure with high crystallinity in all samples.

Figure 3 shows typical SEM photographs of as-prepared $\mathrm{Al}$ doped $\mathrm{LiMn}_{2} \mathrm{O}_{4}$ powders. They had a spherical and irregular morphology. The follow microstructure and fragment of particles were also observed in the large particles. They had also broad size distribution from $0.5 \mu \mathrm{m}$ to $20 \mu \mathrm{m}$ because the mist atomized by two-fluid nozzle had broad size distribution. SEM photograph suggested that

(a)

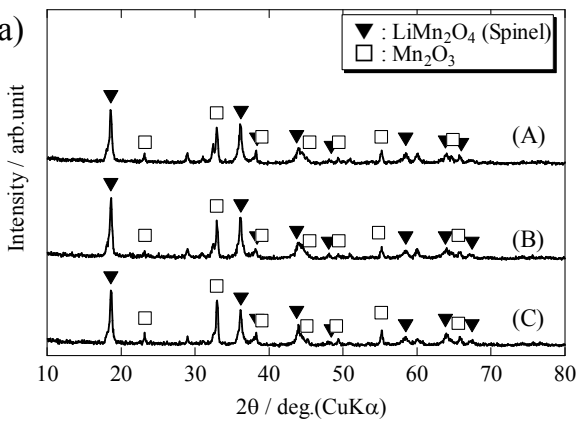

(b)

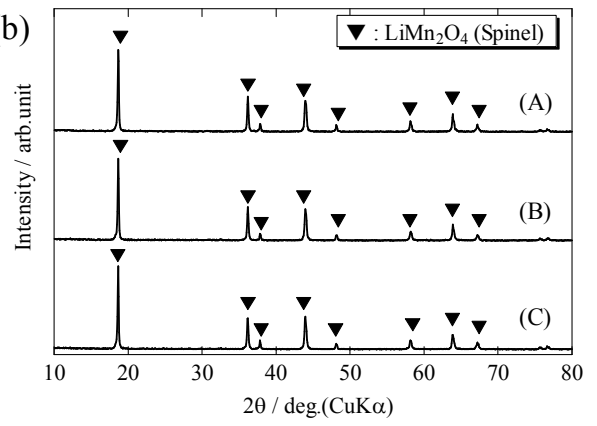

Fig. 2 XRD patterns of $\mathrm{Al}$ doped $\mathrm{LiMn}_{2} \mathrm{O}_{4}$ powders, (a) as-prepared, (b) $800{ }^{\circ} \mathrm{C}$ for $4 \mathrm{hr}$, (A) $\mathrm{Al}(\mathrm{OH})_{3}$, (B) $\mathrm{Al}\left(\mathrm{NO}_{3}\right)_{3}$, (C) $\mathrm{Al}_{2} \mathrm{O}_{3}$. 
they consisted of primary particles. Specific surface area of as-prepared Al doped $\mathrm{LiMn}_{2} \mathrm{O}_{4}$ powders derived from $\mathrm{Al}_{2} \mathrm{O}_{3}$ nanopowders, $\mathrm{Al}\left(\mathrm{NO}_{3}\right)_{3} \cdot 9 \mathrm{H}_{2} \mathrm{O}$ and $\mathrm{Al}(\mathrm{OH})_{3}$ was $18.7,19.4$ and $19.1 \mathrm{~m}^{2} / \mathrm{g}$, respectively. Figure 4 shows typical SEM photographs of $\mathrm{Al}$ doped $\mathrm{LiMn}_{2} \mathrm{O}_{4}$ powders calcined at $800^{\circ} \mathrm{C}$. After the calcination, the primary particles ranged from $100 \mathrm{~nm}$ to $200 \mathrm{~nm}$ were observed in all samples. The primary particles were sintered and then formation of the crystal habit such as a tetrahedron was also observed. Specific surface area of $\mathrm{Al}$ doped $\mathrm{LiMn}_{2} \mathrm{O}_{4}$ powders derived from $\mathrm{Al}_{2} \mathrm{O}_{3}$ nanopowders, $\mathrm{Al}\left(\mathrm{NO}_{3}\right)_{3} \cdot 9 \mathrm{H}_{2} \mathrm{O}$ and $\mathrm{Al}(\mathrm{OH})_{3}$ decreased to $4.1,4.3$ and $3.4 \mathrm{~m}^{2} / \mathrm{g}$, respectively. It was concluded that the microstructure was not influenced by the types of doping agent.

Figure 5 shows the first charge and discharge capacities of $\mathrm{Al}$ doped $\mathrm{LiMn}_{2} \mathrm{O}_{4}$ cathode at $25^{\circ} \mathrm{C}$ and $50{ }^{\circ} \mathrm{C}$. The rechargeable rate was $1 \mathrm{C}$. The voltage jump was observed at around $4 \mathrm{~V}$ in the charge and discharge curves. The discharge capacity of $\mathrm{Al}$ doped $\mathrm{LiMn}_{2} \mathrm{O}_{4}$ cathode obtained from $\mathrm{Al}_{2} \mathrm{O}_{3}$ nanopowders, $\mathrm{Al}\left(\mathrm{NO}_{3}\right)_{3} \cdot 9 \mathrm{H}_{2} \mathrm{O}$ and $\mathrm{Al}(\mathrm{OH})_{3}$ were 110,110 and $108 \mathrm{mAh} / \mathrm{g}$ at $25^{\circ} \mathrm{C}$, respectively. The voltage jump of $4 \mathrm{~V}$ slightly disappeared in discharge curve of all samples. The discharge capacity of $\mathrm{Al}$ doped $\mathrm{LiMn}_{2} \mathrm{O}_{4}$ cathode obtained from $\mathrm{Al}_{2} \mathrm{O}_{3}$ nanopowders, $\mathrm{Al}\left(\mathrm{NO}_{3}\right)_{3} \cdot 9 \mathrm{H}_{2} \mathrm{O}$ and $\mathrm{Al}(\mathrm{OH})_{3}$ were 98 , 113 and $93 \mathrm{mAh} / \mathrm{g}$ at $50{ }^{\circ} \mathrm{C}$, respectively. Figure 6 shows relation between cycle number and discharge capacity of $\mathrm{Al}$ doped $\mathrm{LiMn}_{2} \mathrm{O}_{4}$ cathode at $25{ }^{\circ} \mathrm{C}$ and $50{ }^{\circ} \mathrm{C}$. The discharge capacity of $\mathrm{Al}$ doped $\mathrm{LiMn}_{2} \mathrm{O}_{4}$ cathodes gradually decreased with increasing cycle number at $1 \mathrm{C}$. After 100 cycles at $25{ }^{\circ} \mathrm{C}$, the discharge capacity of $\mathrm{Al}$ doped $\mathrm{LiMn}_{2} \mathrm{O}_{4}$ cathode obtained from $\mathrm{Al}_{2} \mathrm{O}_{3}$ nanopowders, $\mathrm{Al}\left(\mathrm{NO}_{3}\right)_{3} \cdot 9 \mathrm{H}_{2} \mathrm{O}$ and $\mathrm{Al}(\mathrm{OH})_{3}$ was 82,79 and $76 \mathrm{mAh} / \mathrm{g}$, respectively. The retention ratio of discharge capacity was 75,72 and $70 \%$, respectively. It was found that the rechargeable capacity of cathode was influenced by the dispersibility of doping agent in the starting solution. It was considered that $\mathrm{Al}$ dope $\mathrm{LiMn}_{2} \mathrm{O}_{4}$ derived from $\mathrm{Al}\left(\mathrm{NO}_{3}\right)_{3} \cdot 9 \mathrm{H}_{2} \mathrm{O}$ exhibited highest rechargeable capacity among the doping agent because $\mathrm{Al}\left(\mathrm{NO}_{3}\right)_{3} \cdot 9 \mathrm{H}_{2} \mathrm{O}$ was only dissolved in the starting solution. On the other hand, since $\mathrm{Al}(\mathrm{OH})_{3}$ and $\mathrm{Al}_{2} \mathrm{O}_{3}$ was not dissolved in the starting solution, the homogeneity of aluminum ion in $\mathrm{LiMn}_{2} \mathrm{O}_{4}$ particles was lower that of $\mathrm{LiMn}_{2} \mathrm{O}_{4}$ particles derived from $\mathrm{Al}\left(\mathrm{NO}_{3}\right)_{3} \cdot 9 \mathrm{H}_{2} \mathrm{O}$. On the other hand, the discharge capacity was significantly reduced at $50{ }^{\circ} \mathrm{C}$, The discharge capacity of $\mathrm{Al}$ doped $\mathrm{LiMn}_{2} \mathrm{O}_{4}$ cathode obtained from $\mathrm{Al}_{2} \mathrm{O}_{3}$ nanopowders, $\mathrm{Al}\left(\mathrm{NO}_{3}\right)_{3} \cdot 9 \mathrm{H}_{2} \mathrm{O}$ and $\mathrm{Al}(\mathrm{OH})_{3}$ were 38 , 49 and $17 \mathrm{mAh} / \mathrm{g}$ after 100 cycles at $50{ }^{\circ} \mathrm{C}$, respectively. This result suggested that the dissolution of $\mathrm{Mn}$ ion occurred in all samples even though aluminum ion was doped to $\mathrm{LiMn}_{2} \mathrm{O}_{4}$ particles. The retention ratio of discharge capacity was 39,43 and $18 \%$, respectively.

(a)

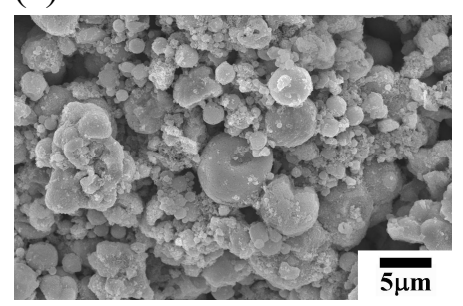

(b)

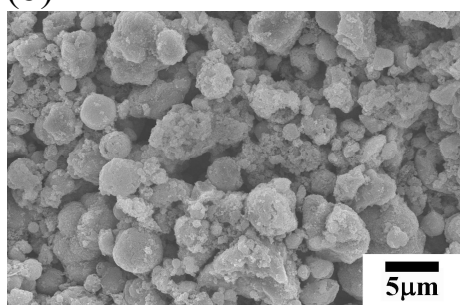

(c)

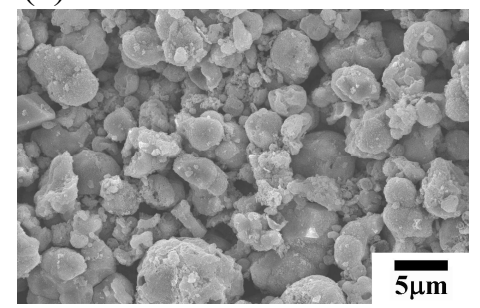

Fig. 3 SEM photograph of as-prepared $\mathrm{Al}$ doped $\mathrm{LiMn}_{2} \mathrm{O}_{4}$ powders.

(a) $\mathrm{Al}_{2} \mathrm{O}_{3}$ nanopowders, (b) $\mathrm{Al}\left(\mathrm{NO}_{3}\right)_{3} \cdot 9 \mathrm{H}_{2} \mathrm{O}$, (c) $\mathrm{Al}(\mathrm{OH})_{3}$.

(a)

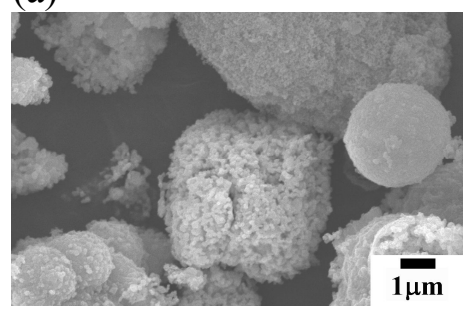

(b)

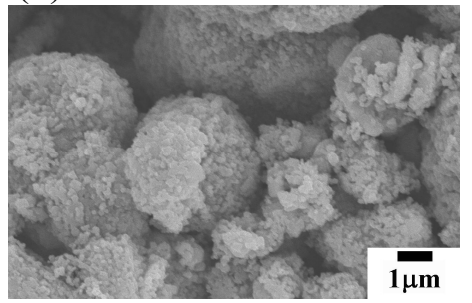

(c)

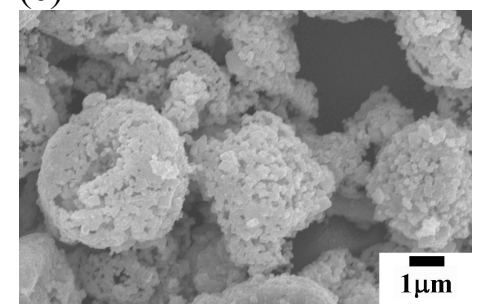

Fig. 4 SEM photograph of $\mathrm{Al}$ doped $\mathrm{LiMn}_{2} \mathrm{O}_{4}$ powders calcined at $800{ }^{\circ} \mathrm{C}$.

(a) $\mathrm{Al}_{2} \mathrm{O}_{3}$ nanopowders, (b) $\mathrm{Al}\left(\mathrm{NO}_{3}\right)_{3} \cdot 9 \mathrm{H}_{2} \mathrm{O}$, (c) $\mathrm{Al}(\mathrm{OH})_{3}$. 
(a)

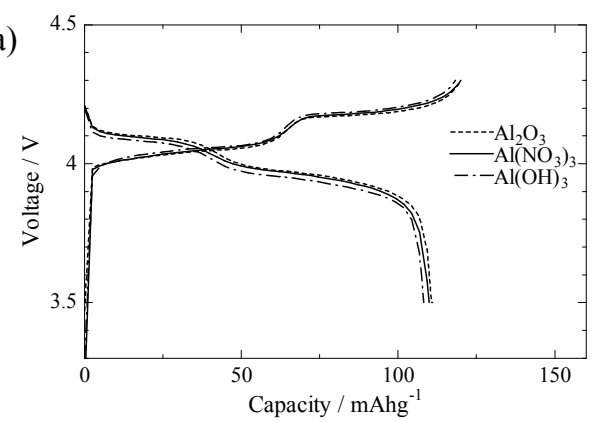

(b)

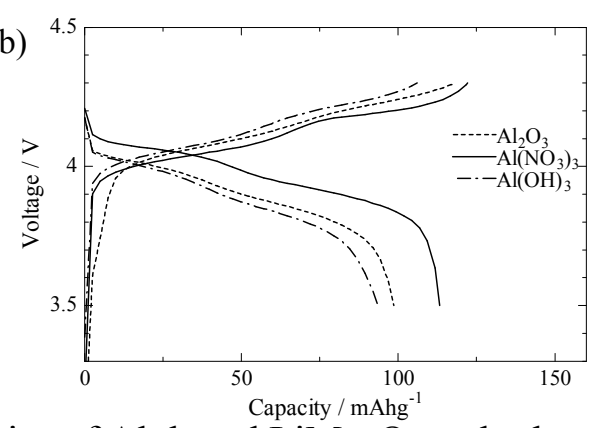

Fig. 5 First charge and discharge capacities of $\mathrm{Al}$ doped $\mathrm{LiMn}_{2} \mathrm{O}_{4}$ cathode,

(a) $25^{\circ} \mathrm{C}$, (b) $50{ }^{\circ} \mathrm{C}$.

(a)

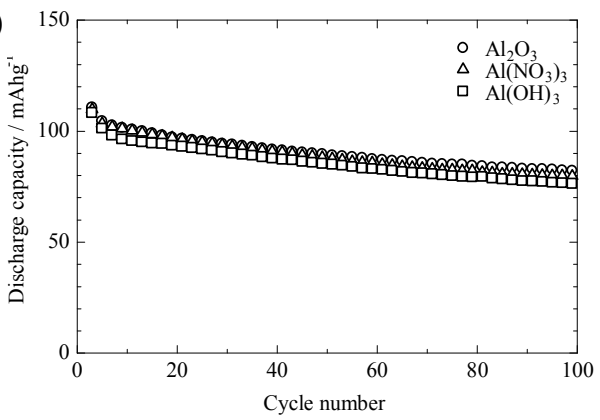

(b)

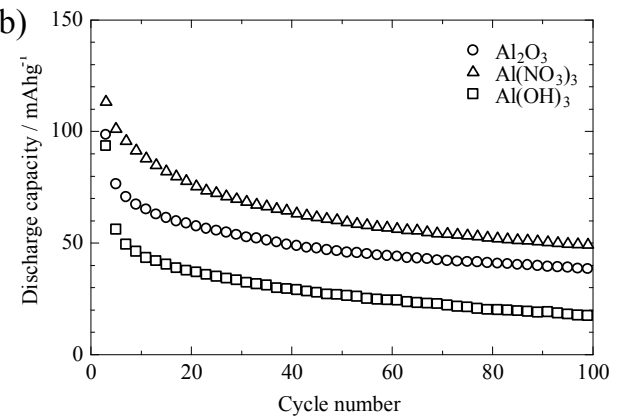

Fig. 6 Relation between cycle number and discharge capacity of $\mathrm{Al}$ doped $\mathrm{LiMn}_{2} \mathrm{O}_{4}$ cathode, (a) $25^{\circ} \mathrm{C}$, (b) $50{ }^{\circ} \mathrm{C}$.

\section{Conclusion}

Al doped $\mathrm{LiMn}_{2} \mathrm{O}_{4}$ powders were prepared by spray pyrolysis using an aqueous solution of manganese carbonate. $\mathrm{Al}$ doped $\mathrm{LiMn}_{2} \mathrm{O}_{4}$ powders had spherical and irregular morphology and consisted of the primary particles. The crystal phase of them was good agreement with spinel phase. The discharge capacity of $\mathrm{Al}$ doped $\mathrm{LiMn}_{2} \mathrm{O}_{4}$ cathode obtained from $\mathrm{Al}_{2} \mathrm{O}_{3}$ nanopowders was 110 $\mathrm{mAh} / \mathrm{g}$. $75 \%$ of initial discharge capacity was maintained after 100 cycles. The discharge capacity of $\mathrm{Al}$ doped $\mathrm{LiMn}_{2} \mathrm{O}_{4}$ cathode obtained from $\mathrm{Al}_{2} \mathrm{O}_{3}$ nanopowders was $82 \mathrm{mAh} / \mathrm{g}$ at $50{ }^{\circ} \mathrm{C} .39 \%$ of initial discharge capacity was maintained after 100 cycles.

\section{Acknowledgement}

This work was supported by Development of an Electric Energy Storage System for Grid-connection with New Energy Resources in New Energy and Industrial Technology Development Organization.

\section{References}

[1] E. Karden, S. Ploumen, B. Fricke, T. Miller and K. Snyder : J. Power Sources 168 (2007), p. 2

[2] Z. Pegeng, F. Huiqing, F. Yunfei, L. Zhuo and D. Yongli : Rare Metals 25 (2006), p. 100

[3] T. Ogihara, N. Ogata, K. Katayama and Y. Azuma : Electrochemistry 68 (2000), p. 162

[4] K. Myoujin, T. Ogihara, N. Ogata, N. Aoyagi, H. Aikiyo, T. Ookawa, S. Omura, M. Yanagimoto, M. Uede and T. Oohara : Adv. Powder Technol. 15 (2004), p. 397

[5] I. Taniguchi, D. Song and M. Wakihara : J. Power Sources 109 (2002), p. 333

[6] M.M. Thackeray : J. Electrochem. Soc. 142 (1995), p. 2558

[7] A. Kock, E. Ferg, R.J. Gummow : J. Power Sources 70 (1998), p. 247

[8] H. Kobayashia, H. Sakaebe, K. Komoto, H. Kageyama, M. Tabuchi, K. Tatsumia, T. Kohigashi, M. Yonemura, R. Kanno, T. Kamiyama : Solid State Ionics 156 (2003), p. 309

[9] K.M. Shaju, G.V. Subba Rao, B.V.R. Chowdari : Solid State Ionics 148 (2002), p. 343 
Electroceramics in Japan XIV

doi:10.4028/www.scientific.net/KEM.485

Synthesis and Electrochemical Properties of Al Doped Lithium Manganate Powders by Spray Pyrolysis Using Carbonate Aqueous Solution

doi:10.4028/www.scientific.net/KEM.485.111 